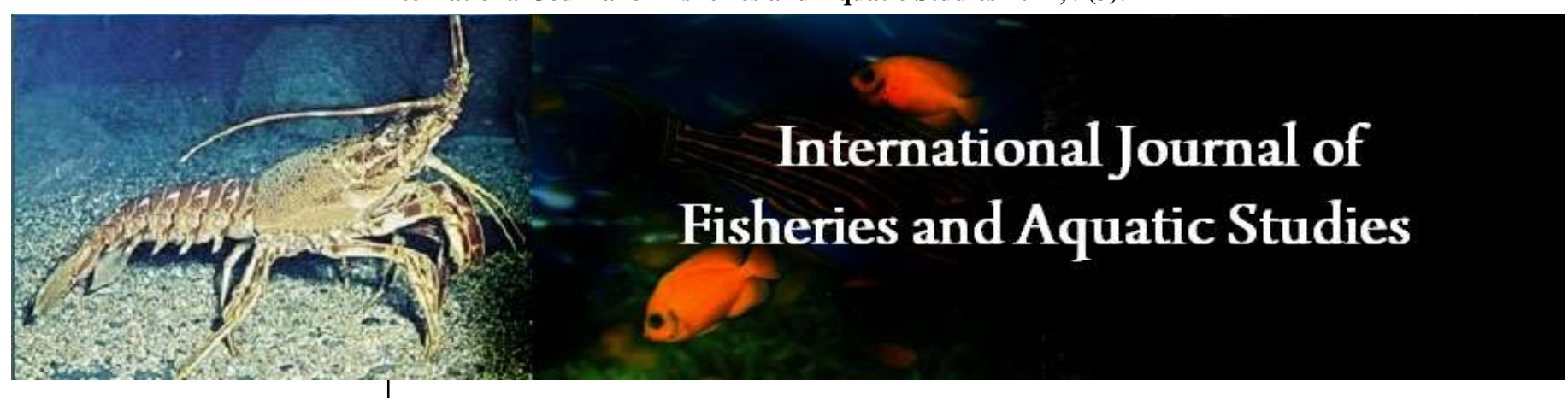

E-ISSN: 2347-5129

P-ISSN: 2394-0506

(ICV-Poland) Impact Value: 5.62

(GIF) Impact Factor: 0.549

IJFAS 2021; 9(3): 12-21

(C) 2021 IJFAS

www.fisheriesjournal.com

Received: 08-02-2021

Accepted: 11-03-2021

Agni Prasad Nepal

School of Science, Kathmandu

University, Dhulikhel, Nepal

Subodh Sharma

School of Science, Kathmandu

University, Dhulikhel, Nepal

Ram C Bhujel

Aquaculture and Aquatic

Resources Management, Asian

Institute of Technology,

Thailand

Tek Bahadur Gurung

Faculty of Animal Sc.

Veterinary Sc. and Fisheries,

Agriculture and Forestry

University, Nepal

Corresponding Author:

Agni Prasad Nepal

School of Science, Kathmandu

University, Dhulikhel, Nepal

\section{Condition factor, growth performance, and production of Rainbow trout (Oncorhynchus mykiss) in floating cages in a shallow reservoir in Panauti, Nepal: A preliminary study}

\author{
Agni Prasad Nepal, Subodh Sharma, Ram C Bhujel and Tek Bahadur \\ Gurung
}

DOI: https://doi.org/10.22271/fish.2021.v9.i3a.2471

\begin{abstract}
Rainbow trout (Oncorhynchus mykiss) is getting priority in aquaculture in Nepal. However, high investments, slow growth in land-based/raceway systems are major challenges. Country would be benefited, if lakes/reservoirs could be utilized for its cage culture. A preliminary trial was conducted in a shallow-reservoir created for hydropower installing three cages, $6 \mathrm{~m} \times 4 \mathrm{~m} \times 2 \mathrm{~m}$ size to evaluate its growth and production potential. The trout juveniles of 57.6 $\pm 15.4 \mathrm{~g}$ (average weight $\pm \mathrm{SD}$ ) were stocked and fed with $33 \%$ crude protein diet twice daily at maximum $3 \%$ of body weight for 91 -days. A random sample of 50 fish per cage was measured total length and body weight each month. Results showed that it is possible to achieve high survival $(96.6 \pm 1.7 \%)$ with reasonable growth rate $\left(0.8 \pm 0 \mathrm{~g}^{-f i s h} \mathrm{fi}^{-1}\right)$ and productivity $\left(89 \pm 27 \mathrm{~kg} . \mathrm{cage}^{-1}\right)$ with fair condition factor $(1.2 \pm 0.1)$ when stocked $10-20$ fish. $\mathrm{m}^{-3}$. These parameters implied that farming of rainbow trout in the shallow reservoir could be successfully done during winter-spring season in a year. However, further research is needed with stocking densities, feeds and feeding rates/methods, and also conducting longer period which may further enhance the productivity thereby profitability.
\end{abstract}

Keywords: Cage culture, coldwater resources, condition factor, growth performance, rainbow trout

\section{Introduction}

Rainbow trout (Oncorhynchus mykiss) is emerging as one of the most suitable species to grow in cold waters of mountainous regions of Nepal, majority of which are originated from the Himalaya ${ }^{[1-3]}$. Rainbow trout requires clean and coldwater not exceeding $20^{\circ} \mathrm{C}$ with relatively high dissolved oxygen having $\mathrm{pH}$ ranging from 6.5 to 9.0 , with slightly alkaline water for growth, in general. Optimum water temperature is $13-20{ }^{\circ} \mathrm{C}$ for best feed intake and growth ${ }^{[2}$, 4]. For few hours, trout are not seriously harmed at temperatures up to $23{ }^{\circ} \mathrm{C}$ but should not remain for longer ${ }^{[5,6]}$. High survival depends on water temperatures remaining at $20{ }^{\circ} \mathrm{C}$ or lower ${ }^{[7]}$ and $25^{\circ} \mathrm{C}$ is the lethal ${ }^{[8]}$.

Trout farming in Nepal is being scaled up as the private sector is adopting it, so stakeholders are exploring the possible locations and ways for its cultivation including cage culture in reservoirs $[3,9,10]$. The country possesses about 6,000 rivers with tremendous potential for hydro-electric power. Therefore, many reservoirs are being created. Cage culture of trout would be one of the best options to utilize the reservoirs for improving livelihoods of fisher community, especially supports for those families who might lose their land due to inundation. More research is needed to develop suitable models for adoption and utilize the coldwater resources. The government has been promoted rainbow trout aquaculture to generate income and employments especially for hilly areas. Trout culture is land-based and raceway system in Nepal. However, high investment and slow growth are major challenges. Cage culture of rainbow trout is practiced widely in many other countries ${ }^{[11-15]}$ There are several advantages of cage culture as it allows complete harvesting in the spring when the water temperature rises above their tolerance limits ${ }^{[7,16]}$. 
Rainbow trout survive and grow well in cages as they adapt well to crowded condition, readily eat pellet feed and there is free exchange of dissolved oxygen from the surrounding water in the lake, ocean or reservoir ${ }^{[14]}$. Especially cage fish culture is beneficial to grow advanced juvenile of desirable size i.e. $200 \mathrm{~g}$ individual body weight ${ }^{[11]}$.

Since, Nepal is rich in freshwater resources, sustainable use of coldwater lakes and reservoirs would be good options for enhancing trout fish production in the country. There is a lack of information on cage culture of rainbow trout in lakes and reservoirs in Nepal. A feasibility study to observe growth and survival was carried out during winter-spring season from November to May in Phewa Lake [10]. However, no information is available about the health with estimation of condition factor and profitability.

Rainbow trout normally has grown 200-300 g in 12 months in Nepal, where water temperature ranges $10-20{ }^{\circ} \mathrm{C}{ }^{[1]}$. However, it depends upon the suitable range of water temperature, dissolved oxygen, $\mathrm{pH}$ and other water quality parameters. How to enhance its growth, ensure high productivity and profitability are the major challenges. Farmers need to choose a suitable stocking density and feeding rates as major management strategies. At lower stocking densities, fish may grow fast or bigger, but at higher densities, they may get stress and might grow slower. The knowledge of length-weight relationship, condition factor (K), survival and growth rates are basic and important parameters test or comparison by good fisheries managers ${ }^{[17-20]}$. Because, these express the state of the health, general fitness reared in specific system [18, 21-24]. Based on these facts important decisions are drawn implying histology, morphological comparisons, marketing and profitability of aquaculture practices adopted. The fitness of fish is influenced by growth, age, sex, season, stage of maturation, food availability, fullness of gut, type of food consumed, amount of fat reserve and degree of muscular development ${ }^{[25,26]}$

The sudden change in water quality in land-based systems is an important limiting factor in fish development. Factors such as water temperature, turbidity, flow velocity, pathogenic microorganism load are the main factors of these stresses. However, changes in meteorological conditions in reservoirs such as dams, lakes and ponds will not cause sudden changes in water quality. The studies on rainbow trout in Nepal are mostly focusing on farming practices in land-based/raceways after its introduction from Japan in $1988^{[3]}$. There are very limited studies related to important parameters such as lengthweight relations, $\mathrm{K}$ factor and growth, production and profitability of trout especially for cage culture in reservoirs. Therefore, feasibility of rainbow trout in a shallow reservoir created due to hydropower project was examined evaluating these parameters with the hypothesis that rainbow trout could be reared in cages during winter up to spring successfully.

\section{Materials and Methods}

\subsection{Experimental site}

This short term evaluation was performed in a reservoir of approximately 1.0 hectares in total area with 4.0 meter of maximum depth from top level of water surface. The reservoir is situated at around $1,450 \mathrm{~m}$ above mean sea level, $27^{\circ} 33^{\prime} 53.5^{\prime \prime} \mathrm{N}, 85^{\circ} 32^{\prime} 00.3^{\prime \prime} \mathrm{E}$, built to provide a run-of the river structure for Panauti Hydropower Station at Khopasi, Panauti-10 in Kavrepalanchowk district about 35 km SouthEast of Kathmandu with installed capacity of $2.4 \mathrm{MW}$ power. The reservoir receives the water supply from nearby
Roshikhola, a tributary of Sunkoshi River. The climate of Panauti is wet and dry having an average rainfall of about 950-1275 mm per year (3 years record of 2017-2019).

\subsection{Cages and the fish for experiment}

The rainbow trout fingerlings were procured from Bhandari Rainbow Trout Farm, Helambu Rural Municipality, Sindhupalchowk, Nepal. After the transportation fingerlings $(57.6 \pm 15.4 \mathrm{~g})$ were stocked on $1^{\text {st }}$ January 2020 into three cages of $48 \mathrm{~m}^{3}(6 \mathrm{~m} \times 4 \mathrm{~m} \times 2 \mathrm{~m})$ size hanged with readymade plastic floats and anchors from all the four sides. The mesh size of the cage nets was $20 \mathrm{~mm}$ stretched. A sample of 50 fish were taken every month to measure total length and body weight from each cage, where 480, 720 and 960 fish per cage were stocked with stocking rate of 10,15 and 20 fish. $\mathrm{m}^{-3}$, respectively.

\subsection{Water quality}

Water temperature was monitored daily near by the cages in the reservoir. Dissolved oxygen (DO) and $\mathrm{pH}$ were monitored once in a month at 10:00 AM, using a portable data logger pH/ORP, DO, CD/TDS Meter, Lutron, Model No. WA-2015, Bench Type, RS23/USB.

\subsection{Fish Feed and feeding}

Dried sinking pellet feed of $33 \%$ crude protein $(\mathrm{CP})$ content made by local producers was supplied in this study. Feeding rate was maximum $3 \%$ of body weight, which is within the recommended range $(2-5 \%)$ of feeding rate in cage by Wynne [7]. Fish were fed satiation during the lower water temperature $\left(10-13{ }^{\circ} \mathrm{C}\right)$ condition. Unconsumed feed were returned back, weighed and recorded the actual feed consumed. The fish were fed manually in cages, twice daily at 10 am in morning and $4 \mathrm{pm}$ in evening.

\subsection{Fish sampling for length-weight measurement}

Fish were sampled once a month ( $1^{\text {st }}$ day of every month) by collecting representative samples of 50 fish from each cages for total length and body weight measurement. Fish were starved a day before growth checking. After every sampling, new feeding rates were adjusted according to the average weight determined from the sampled fish. At the end of 3 months, the cages were completely dragged and measured for total length (TL) and body weight (BW). The BW was measured with a sensitive digital electronic balance (Shimadzu UX320G) weighing balance with a readability range of $0.10 \mathrm{~g}$ and TL was measured with a measuring board to the nearest $0.10 \mathrm{~cm}$ accuracy. The total length of the fish was taken from the tip of snout (mouth closed) to the tip of the caudal fin. The statistical relationship between these parameters of fishes was established using the parabolic equation as described:

$\mathrm{W}=\mathrm{aL}^{\mathrm{b}}$ : Where, $\mathrm{W}=$ Body weight of fish $(\mathrm{g}), \mathrm{L}=$ total length of fish $(\mathrm{cm}), a=$ constant, $b=$ is the slope of line for the relation between length and weight. The relationship $(\mathrm{W}=\mathrm{aL})$ when converted into the logarithmic form gives a straight line relationship graphically $b \log W=\log a+b$ Log L.

\subsection{Condition Factor $(\mathrm{K})$}

The coefficient of condition ' $\mathrm{K}$ ' was calculated by using Fulton equation ${ }^{[25]} ; \mathrm{K}=\mathrm{W} / \mathrm{L}^{3} \times 100$,

where, $\mathrm{W}=$ weight in grams, $\mathrm{L}=$ length in $\mathrm{mm}$, and 100 is a factor to bring the value of $\mathrm{K}$ near unity. Condition factor was 
calculated from the formulae;

$\mathrm{CF}=100 \mathrm{~W}(\mathrm{~g}) / \mathrm{L}(\mathrm{cm})^{3}$, where, $\mathrm{W}=$ body weight and $\mathrm{L}=$ total length.

\subsection{Absolute Growth Rate (AGR)}

Since rainbow trout is being farmed, reporting fish growth in terms of more desirable expression. Absolute growth rates (g/d) implies that the relationship of increased weight to time. AGR) was calculated using the following formula described by Hopkins ${ }^{[18]}$ and Lugert et al. ${ }^{[27]}$.

$\mathrm{AGR}=(\mathrm{Wf}-\mathrm{Wi}) / \mathrm{t}$,

where, $\mathrm{Wf}=$ final weight /length, $\mathrm{Wi}=$ initial weight/length, and ' $\mathrm{t}$ ' is the time interval.

\subsection{Fish survival and feed conversion ratio (FCR)}

Survival of fish was considered the remaining fish after deducting the number of died, missing or escaped. Following formula was used for calculating the survival percentage:

Survival rate $(\%)=$ number of fish alive at harvest/number of initial stock $\times 100$.

FCR was calculated as total feed consumed divided by weight gain using following formula ${ }^{[28]} \mathrm{FCR}=\mathrm{FC} / \mathrm{A}_{2}-\mathrm{A}_{1}$ ), where, $\mathrm{FC}=$ Feed consumption, $\mathrm{A}_{1}=$ Total weight at beginning of the period, $\mathrm{A}_{2}=$ Total weight at end of the period

\subsection{Statistical analysis}

One-way analysis of co-variance (ANCOVA) was used to compare the mean of some growth and production parameters among treatments. The growth model of fish with time was drawn using linear regression. The effect of stocking density on the final biomass was explained by using exponential model while that on feed efficiency was by quadratic relation. The relationship between length and weight of fish was analyzed by measuring length and weight of fish specimen. The value of constants ' $a$ ' and ' $b$ ' was estimated by linear regression after logarithmic transformation of weight and length data by using formula: $\log \mathrm{W}=\log a+b \log$. The data were analyzed using statistical tools available in the MS Excel 2013 and XLSTAT 2014.5.03.

\section{Results}

\subsection{Growth performance}

The summary of some basic features on stocking rate, initial and final body weight, growth, harvest number, FCR of rainbow trout has been given in Table 1 . The average final (harvested) body weight of rainbow trout was $128.8 \pm 32.5 \mathrm{~g}$ (ranging from $122.8 \pm 30.5 \mathrm{~g}$ to $136.2 \pm 34.2 \mathrm{~g}$ ) for 91 days growth period. During the study period there was high survival rate $(96.6 \pm 1.7 \%)$ at harvest and the mortality was few probably due to handling during the transfer and sampling activities but not due to prevailing diseases, food or water quality disorders in the reservoir. The feed conversion ratio (FCR) was $2.6 \pm 0.2$ (ranged from 2.2 to 2.8) (Table 1). Mean comparison by one-way analysis of co-variance (ANCOVA) shows that the initial and final body weight among the group was not significantly different $(P>0.05)$ (Table 1, Fig 1). Similarly, the average body length among the groups also was not significant $(P>0.05)$ in initial stocking size and in final size during the growing period (Table 1, Fig 2).

Table 1. Results of the trial, Rainbow trout reared in cages in a shallow reservoir of Nepal

\begin{tabular}{|c|c|c|c|}
\hline Biomass/stock details & 10 fish. $\mathrm{m}^{-3}$ & 15 fish. $\mathrm{m}^{-3}$ & 20 fish. $\mathrm{m}^{-3}$ \\
\hline Total no. of initial stock & 480 & 720 & 960 \\
\hline Initial number of stock density. $\mathrm{m}^{-3}$ & 10 & 15 & 20 \\
\hline Final number of stock density. $\mathrm{m}^{-3}$ & 9.48 & 14.50 & 19.64 \\
\hline Average initial length $(\mathrm{cm}) \pm \mathrm{SD}$ & $16.6 \pm 1.6^{\mathrm{a}}$ & $16.9 \pm 1.6^{\mathrm{a}}$ & $16.3 \pm 1.5^{\mathrm{a}}$ \\
\hline Average final length $(\mathrm{cm}) \pm \mathrm{SD}$ & $22.2 \pm 1.9^{\mathrm{a}}$ & $22.0 \pm 1.9^{\mathrm{a}}$ & $21.6 \pm 2.3^{\mathrm{a}}$ \\
\hline Average initial weight $(\mathrm{g}) \pm \mathrm{SD}$ & $61.5 \pm 16.6^{\mathrm{a}}$ & $58.8 \pm 14.6^{\mathrm{a}}$ & $52.6 \pm 14.9^{a}$ \\
\hline Average final weight $(\mathrm{g}) \pm \mathrm{SD}$ & $136.2 \pm 34.2^{\mathrm{a}}$ & $127.4 \pm 32.7^{\mathrm{a}}$ & $122.8 \pm 30.5^{\mathrm{a}}$ \\
\hline Average weight gaining $(\mathrm{g})$ & $74.7^{\mathrm{a}}$ & $68.6^{\mathrm{a}}$ & $70.2^{\mathrm{a}}$ \\
\hline Average length gaining $(\mathrm{cm})$ & $5.6^{\mathrm{a}}$ & $5.1^{\mathrm{a}}$ & $5.3^{\mathrm{a}}$ \\
\hline Initial stocking density (kg/cage) & 29.5 & 42.3 & 50.5 \\
\hline Final fish numbers (individual/cage) & 455 & 696 & 943 \\
\hline Survival (\%) & 95 & 97 & 98 \\
\hline Gross weight per cage at harvest (kg) & 62.0 & 88.7 & 115.8 \\
\hline Net weight increased per cage $(\mathrm{kg})$ & 32.5 & 46.4 & 65.3 \\
\hline Absolute growth rate (g/fish/d) & 0.83 & 0.78 & 0.76 \\
\hline Consumed feed $(\mathrm{kg})$ & 91.78 & 127.96 & 147.04 \\
\hline Feed efficiency $(\%)$ & $35.4^{\mathrm{a}}$ & $36.3^{\mathrm{a}}$ & $44.4^{\mathrm{a}}$ \\
\hline Feed conversion ratio (FCR) & $2.80 \pm 0.15^{\mathrm{a}}$ & $2.80 \pm 0.21^{\mathrm{a}}$ & $2.30 \pm 0.17^{\mathrm{a}}$ \\
\hline Average condition factor \pm SD & $1.2 \pm 0.13$ & $1.2 \pm 0.15$ & $1.2 \pm 0.13$ \\
\hline
\end{tabular}

The absolute growth rate (AGR) with average final weights and total lengths showed significant linear relationships with rearing period for each stocking densities. The regression equations are presented in Table 2 and Fig 3. According to the regression models the growth rate was $0.83 \mathrm{~g}, 0.78 \mathrm{~g}$ and 0.76 $\mathrm{g}$ per day for lowest, medium and highest densities respectively (Table 1, Fig 3). Similarly, the increase in lengths were $0.0625 \mathrm{~cm}, 0.0584 \mathrm{~cm}$ and $0.0570 \mathrm{~cm}$ for the respective densities (Table 2, Fig 4).

Table 2: Results of regression analysis of relationship between average weight and total length with rearing period, and that of net biomass and feed efficiency with stocking density

\begin{tabular}{|c|c|c|c|c|}
\hline & Equations & $\mathrm{R}^{2}$ & $\mathrm{n}$ & Significance \\
\hline Average weight $(\mathrm{g})$ & $\mathrm{y}=0.8291 \mathrm{x}+56.95$, & 0.977 & 4 & $P<0.01$ \\
\hline & $\mathrm{y}=0.7816 \mathrm{x}+54.636$, & 0.976 & 4 & $P<0.05$ \\
\hline
\end{tabular}




\begin{tabular}{|c|c|c|c|c|}
\hline & $\mathrm{y}=0.762 \mathrm{x}+51.13$ & 0.993 & 4 & $P<0.05$ \\
\hline Total length $(\mathrm{cm})$ & $\mathrm{y}=0.0625 \mathrm{x}+16.384$, & 0.9876 & 4 & $P<0.01$ \\
\hline & $\mathrm{y}=0.0584 \mathrm{x}+16.496$, & 0.9685 & 4 & $P<0.05$ \\
\hline & $\mathrm{y}=0.057 \mathrm{x}+16.22$, & 0.9896 & 4 & $P<0.01$ \\
\hline Net biomass $(\mathrm{kg})$ & $\mathrm{y}=0.146 \mathrm{x}^{2}-3.4788 \mathrm{x}+55.603$ & 1.00 & 3 & $P<0.01$ \\
\hline Feed efficiency & $\mathrm{y}=16.214 \mathrm{e}^{0.0698 \mathrm{x}}$, & 0.9999 & 3 & $P<0.01$ \\
\hline
\end{tabular}

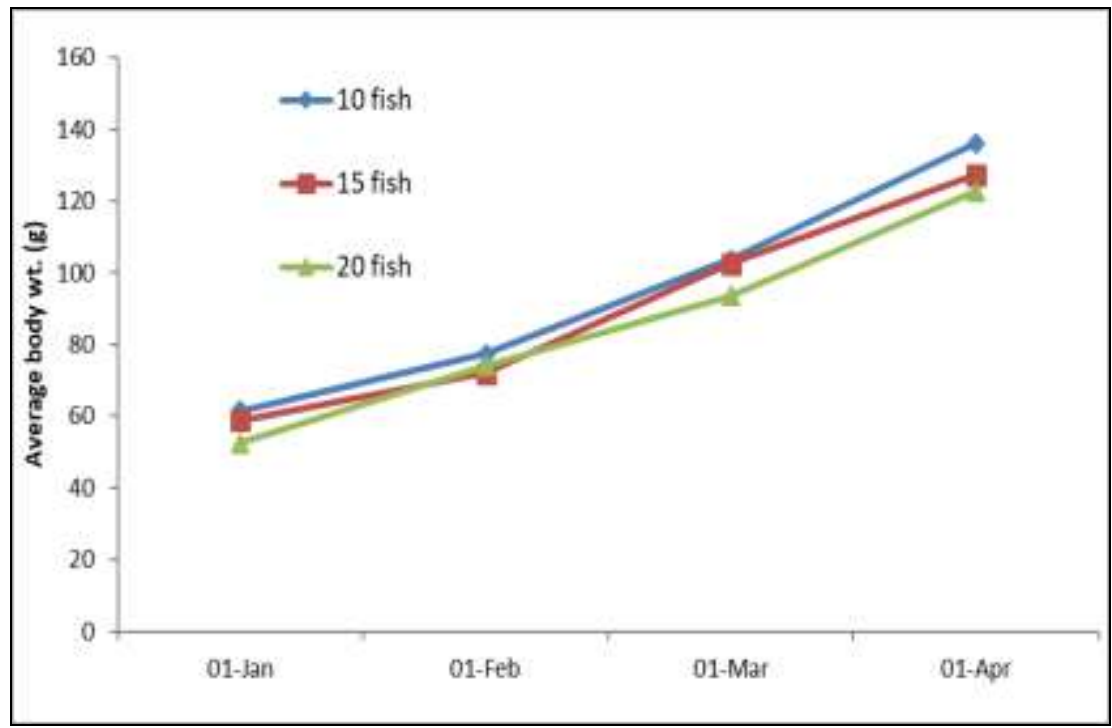

Fig 1: Average body weight $(\mathrm{g})$ of rainbow trout stocked at three densities $\left(10,15\right.$ and 20 fish. $\left.\mathrm{m}^{-3}\right)$ over the rearing period of 91 days from January 1 to April 1, 2020.

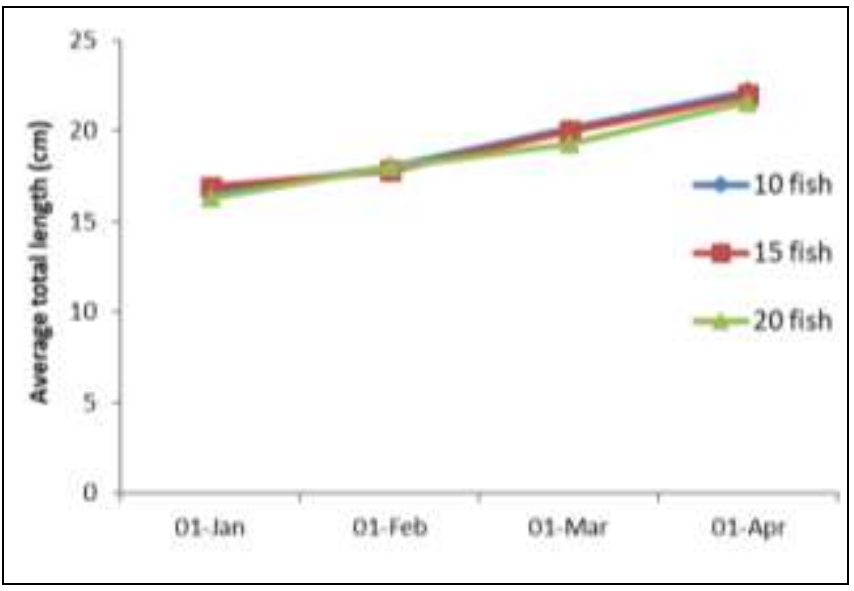

Fig 2: Average total length $(\mathrm{cm})$ of rainbow trout stocked at three densities $\left(10,15\right.$ and 20 fish. $\left.\mathrm{m}^{-3}\right)$ over the rearing period of 91 days from January 1 to April 1, 2020.

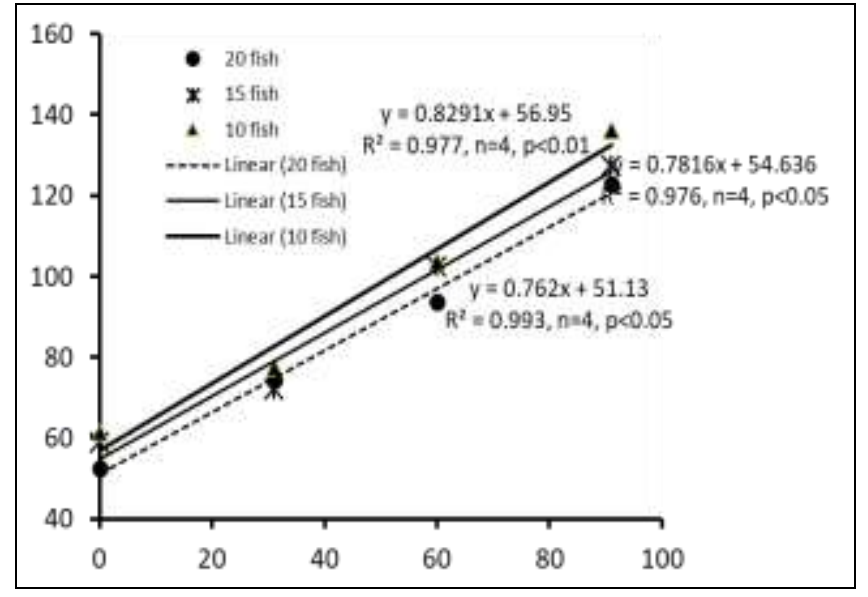

Fig 3: Growth (g, Y-axis) of rainbow trout stocked at three densities $\left(10,15\right.$ and 20 fish. $\mathrm{m}^{-3}$ ) over the rearing period of 91 days (x-axis)

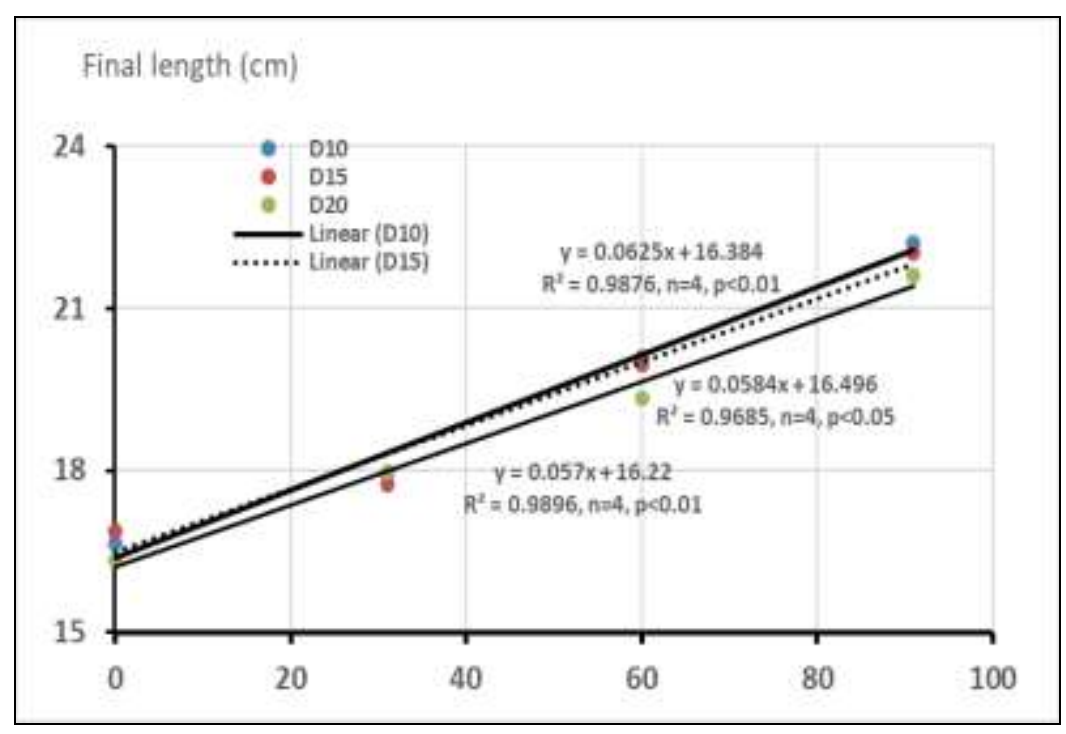


Fig 4: Total lentgh (cm, Y-axis) of Rainbow trout stocked at three densities (10, 15 and 20 fish. $\left.\mathrm{m}^{-3}\right)$ over the rearing period of 91 days (x-axis)

\subsection{Length-weight relationship and condition factor}

For length-weight relationship (LWR) a total of 600 specimens were measured for total length and body weight within the rearing period. The minimum and maximum value of total length of fish ranged from 12.0 to $26.6 \mathrm{~cm}$ and body weight 25.0 to $219.0 \mathrm{~g}$ at stocking to harvesting, respectively (Table 3).

Table 3. Description of rainbow trout examined for maximum and minimum value of total length (TL) and body weight (BW) and regression parameter values, $\mathrm{a}, \mathrm{b}$ and $\mathrm{R}^{2}$.

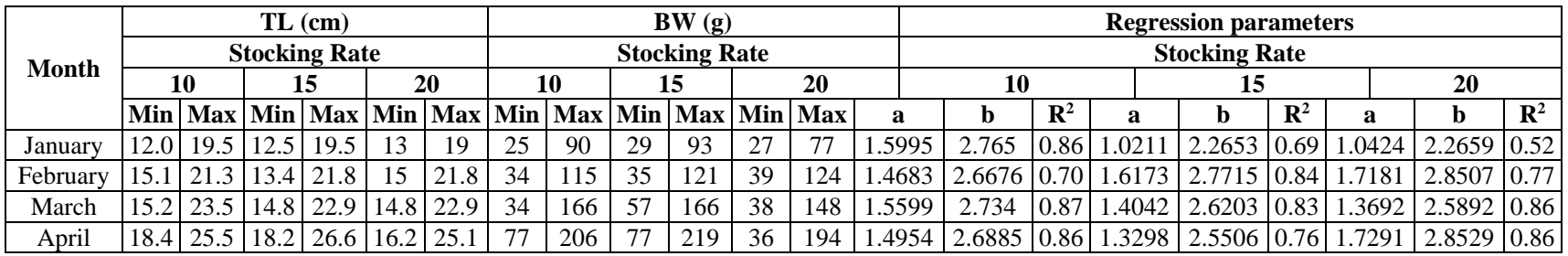

Accumulatively, the simple regression between body weight and total length showed strong relationship $\left(\mathrm{R}^{2}\right)$. The regression equation for length weight relationship (LWR), coefficient of determination $\left(\mathrm{R}^{2}\right)$, growth coefficient (b) is given in Table 3. The average value of $\mathrm{R}^{2}$ was 0.89 reflecting that the increase in body weight was highly correlated to the increasing total length. The value of $\mathrm{R}^{2}$, was $0.92,0.89$ and 0.87 , respectively for 10,15 and 20 fish stocking rate. $\mathrm{m}^{-3}$ (Fig 5), while the 'b' value ranged from 2.265 to 2.853 (Table 3 ).

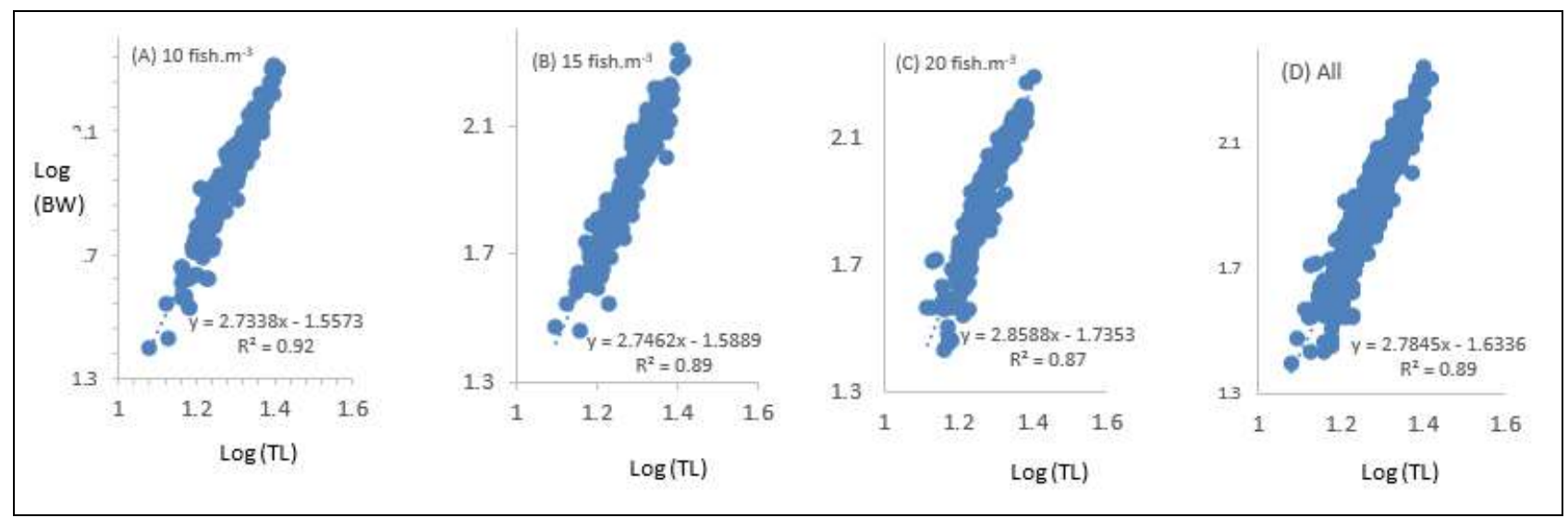

Fig 5: Length and weight relationship of rainbow trout in cage with (A) 10, (B) 15, (C) 20

fish. $\mathrm{m}^{-3}$ stocking density and (D) combination of all

The condition factor $(\mathrm{K})$ value also was calculated from that minimum and maximum value of total length and body weight of total 600 specimens measured in different months of the rearing period. The mean value of condition factor $(\mathrm{K})$ ranged from 1.177 to 1.319 in stocking of 15 fish.m ${ }^{-3}$ and 10 fish. $\mathrm{m}^{-3}$ cages, respectively (Table 4).

Table 4: Condition factor ' $\mathrm{K}$ ' of rainbow trout reared short term in cages of Khopasi Reservoir

\begin{tabular}{|c|c|c|c|c|c|c|c|c|c|c|c|c|}
\hline \multirow{3}{*}{ Month } & \multicolumn{12}{|c|}{ Stocking Rate } \\
\hline & \multicolumn{4}{|c|}{10 fish.m-m ${ }^{-3}$} & \multicolumn{4}{|c|}{15 fish.m-3 } & \multicolumn{4}{|c|}{20 fish.m ${ }^{-3}$} \\
\hline & Min & $\operatorname{Max}$ & Mean & \pm SD & Min & Max & Mean & \pm SD & Min & Max & Mean & \pm SD \\
\hline January & 1.004 & 1.59 & 1.3085 & 0.1497 & 0.7123 & 1.6649 & 1.2144 & 0.1958 & 0.7327 & 2.072 & 1.1997 & 0.2780 \\
\hline February & 0.8548 & 1.9289 & 1.3196 & 0.2032 & 0.9629 & 1.6657 & 1.2610 & 0.150 & 0.8880 & 1.6999 & 1.2561 & 0.1739 \\
\hline March & 0.9220 & 1.5673 & 1.2510 & 0.1414 & 1.0000 & 1.6453 & 1.2744 & 0.1414 & 0.8616 & 1.5786 & 1.2762 & 0.1412 \\
\hline April & 0.9779 & 1.6103 & 1.2236 & 0.1480 & 0.7782 & 1.5008 & 1.1772 & 0.1480 & 0.8478 & 1.5094 & 1.1948 & 0.1268 \\
\hline
\end{tabular}

\subsection{FCR and Feed efficiency}

There was no clear trend in feed conversion ratio (FCR), where the average value was found 2.6 \pm 0.2 ranged from 2.3 to 2.8 (Table 1). However, the relationship between feed efficiency and the stocking density was found to be significant $\left(\mathrm{y}=0.146 \mathrm{x}^{2}-3.4788 \mathrm{x}+55.603, \mathrm{R}^{2}=1, \mathrm{n}=3, P<\right.$ 0.01 , Fig 6). This indicates that feed efficiency was at minimum when stocking density was at 12 fish. $\mathrm{m}^{-3}$. 


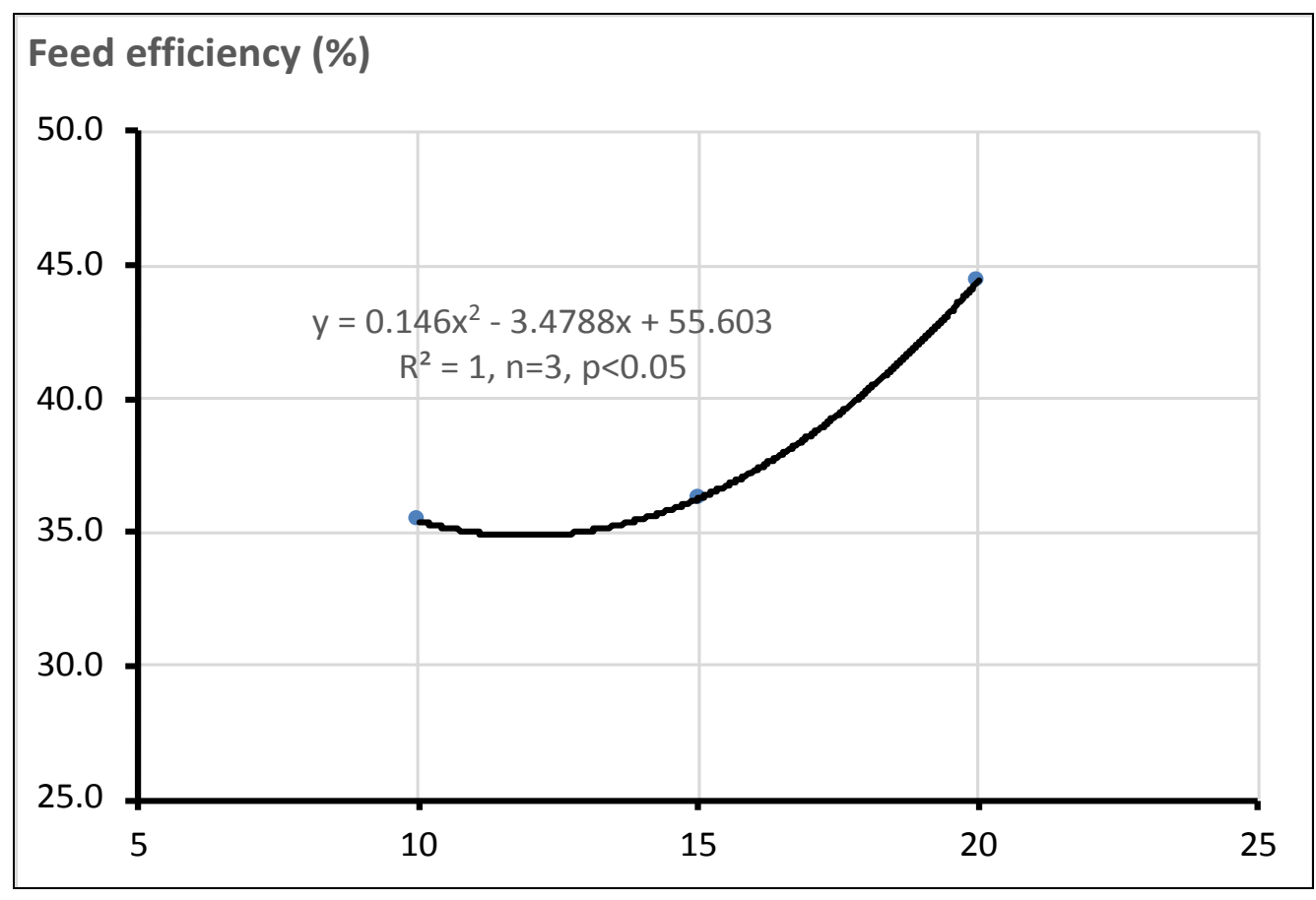

Fig 6: Relationship between feed efficiency (\%) and stocking density (fish. $\mathrm{m}^{-3}$ ) in $\mathrm{x}$-axis

\subsection{Productivity and profitability}

Productivity of trout i.e. net biomass increased exponentially with the increasing stocking density $\left(y=16.214 \mathrm{e}^{0.0698 x}, \mathrm{R}^{2}=\right.$
$0.9999, \mathrm{n}=3, P<0.05$, Fig. 7). The exponential increment rate was found to be $6.98 \%$ per fish. $\mathrm{m}^{-3}$.

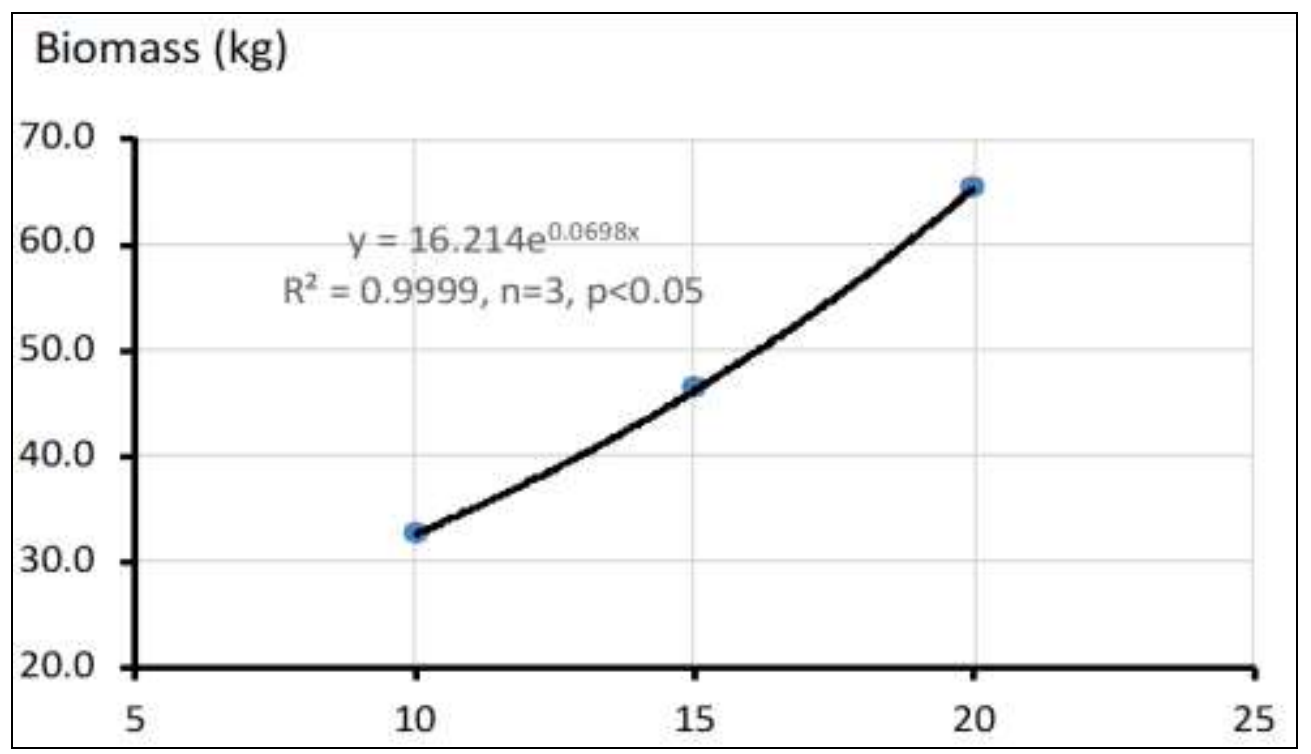

Fig 7: Relationship between biomass and stocking density (fish. $\mathrm{m}^{-3}$ ) in $\mathrm{x}$-axis

The result showed that it is possible to achieve high survival $(96.6 \pm 1.7 \%)$ with reasonable growth rate $\left(0.8 \pm 0\right.$ g.fish $\left.^{-1}\right)$ and productivity $\left(89 \pm 27{\left.\mathrm{~kg} . \mathrm{cage}^{-1}\right)}\right.$ with fair condition factor
(1.2 \pm 0.1$)$ (Table 1). Similarly, profitability of the trout culture in net cage was significantly higher in higher density cages (20 fish.m ${ }^{-3}$ ) (Fig 8). 


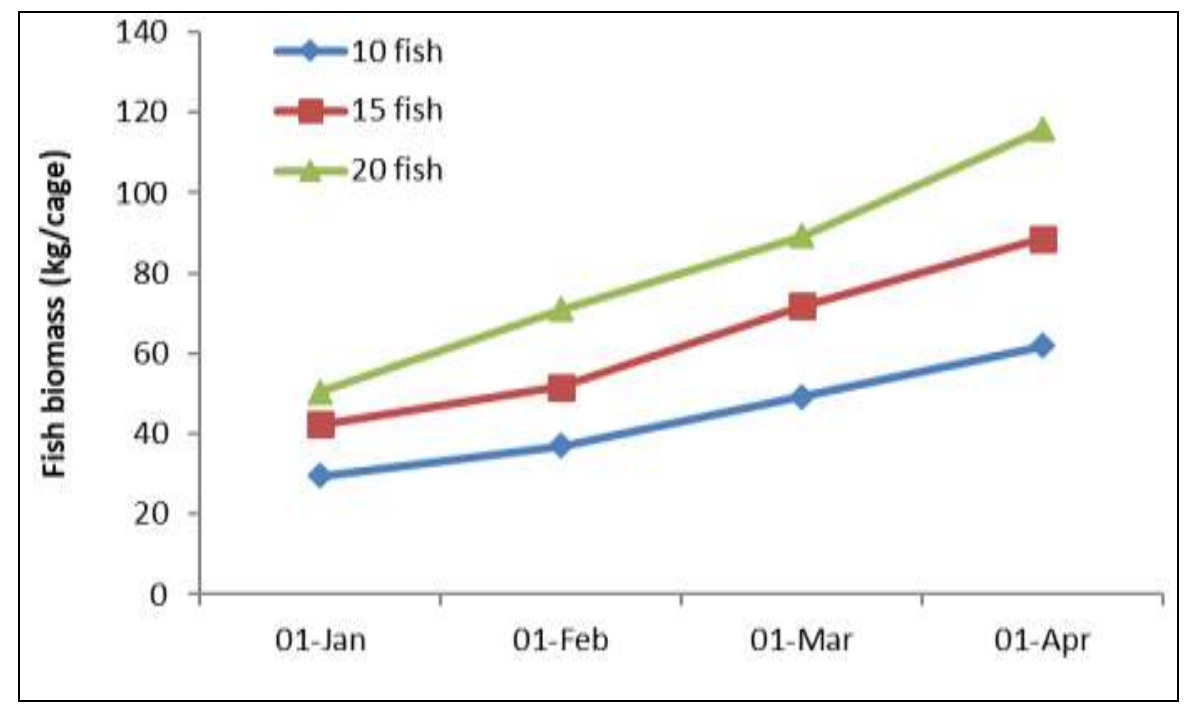

Fig 8: Growth trend in total stock in different stocking density (10,15 and 20 fish.m $\left.{ }^{-3}\right)$ during culture period from January 1 to April 1,2020 at Khopasi Reservoir, Nepal.

Due to a short period experiment cost analysis was based on fingerlings and feed cost. Net income was US\$1.81, 2.18 and $3.01 \mathrm{~m}^{-3}$ from 480, 720 and 960 fish stocked cages with $\mathrm{B} / \mathrm{C}$ ratio $1.20,1.16$ and 1.17 , respectively in this study, where selling price was US\$ $8.52 \mathrm{~kg}^{-1}$, which is a farm gate price in most of the trout farms in the country (Table 5).

Table 5. Cost-benefit of trout culture during winter-spring in small reservoir of Khopasi Nepal.

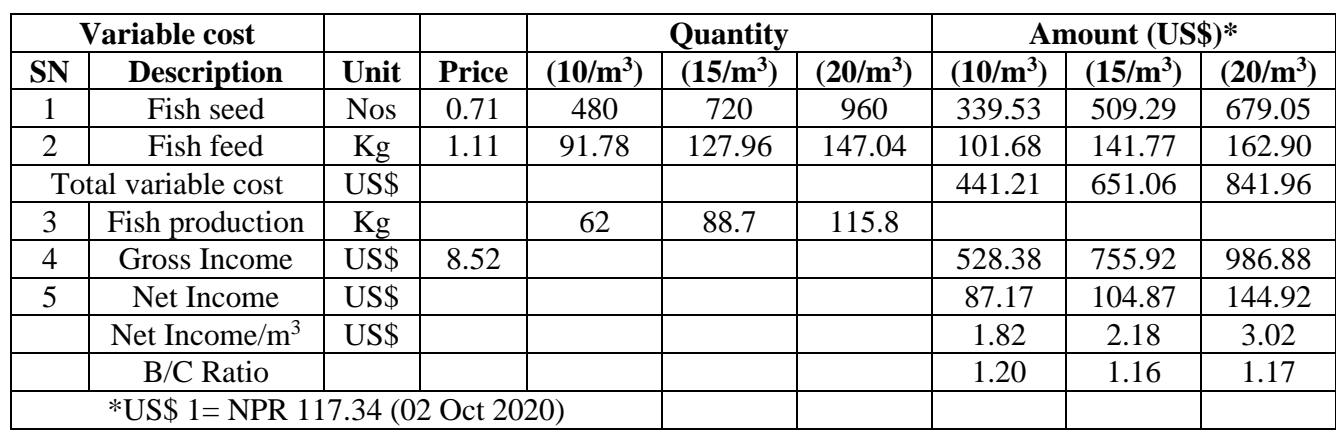

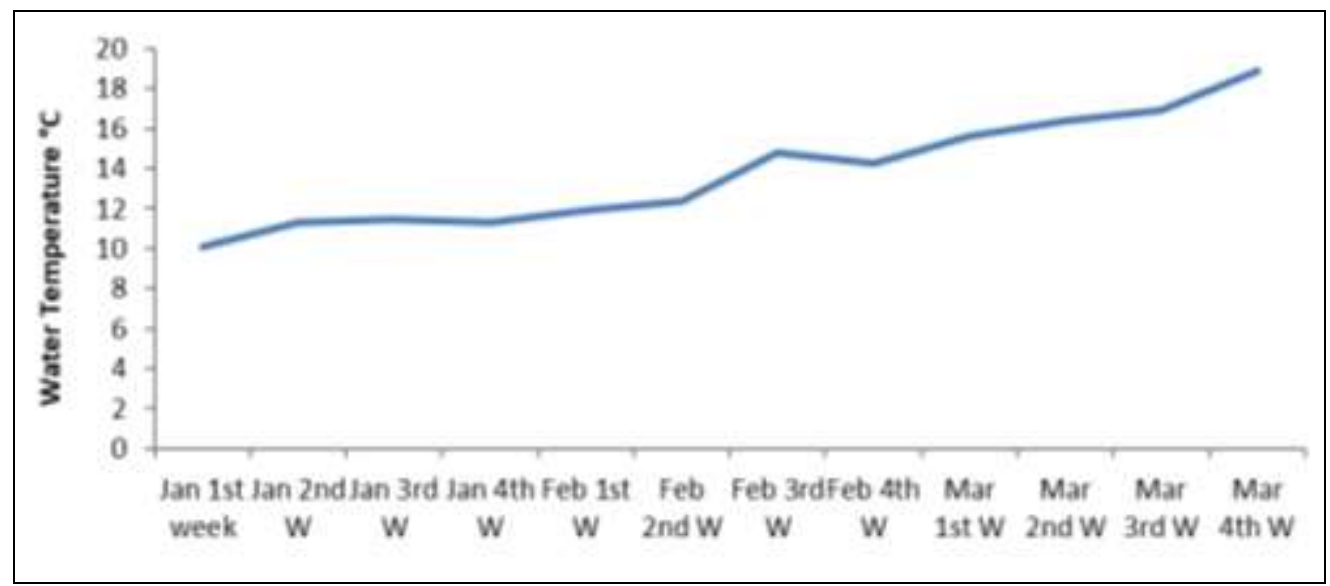

Fig 9: The change in water temperature in the Khopasi Reservoir during the period from January 1 to April 1, 2020. 


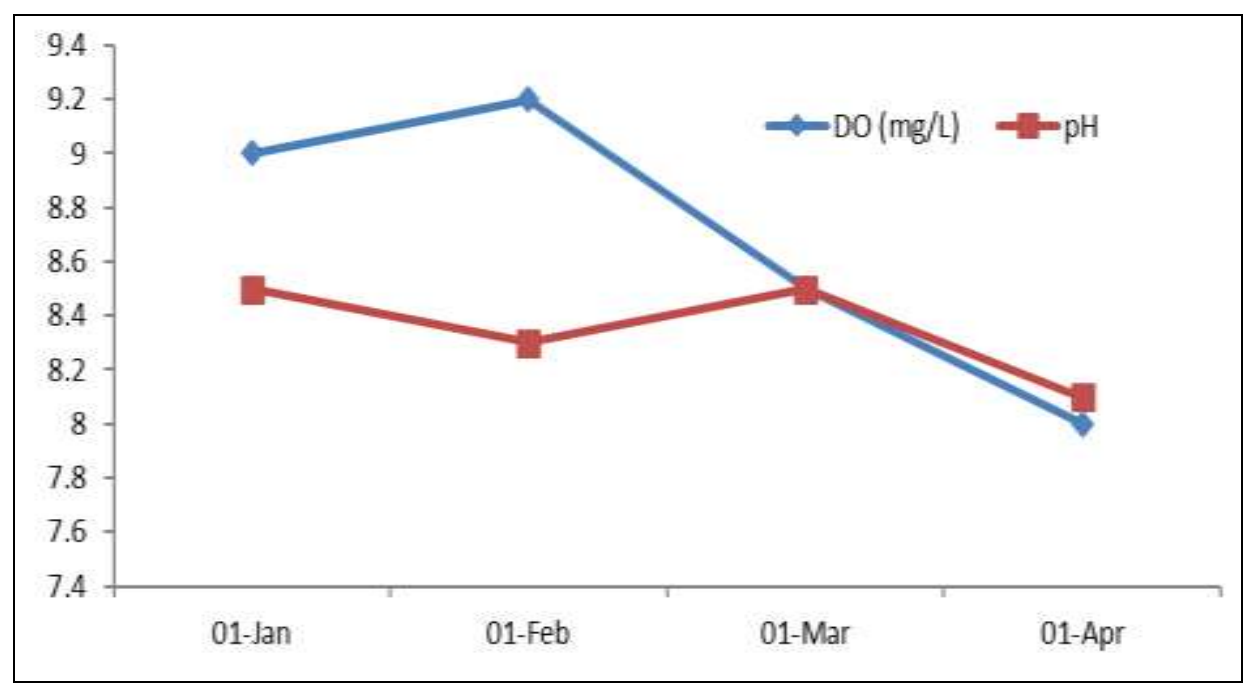

Fig 10: Dissolved Oxygen (mg/L) and $\mathrm{pH}$ value for 4 months during cage culture period of rainbow trout in Khopasi reservoir, Nepal (2020).

\section{Discussion}

Based on the value of length-weight relation, $\mathrm{K}$ factor and absolute growth rates in this study it can be concluded that rainbow trout in cages in Khopasi reservoir can be reared successfully in winter-spring season. There are enough evidences available to suggest the null hypothesis is not rejected at the 95\% confidence level. The length-weight relationship indicated a high degree of positive correlation between these two parameters (Table 2, Fig 1, Fig 2, Fig 3A, $\mathrm{B}, \mathrm{C})$. The pattern of length-weight relationships were within the range reported in earlier studies by Cren ${ }^{[17]}$, Kljajic et al. [29], Sharma and Bhat ${ }^{[23]}$.

Past works showed the value of exponent ' $b$ ' of length-weight relationship fluctuates between 2 to $4^{[30]}$. If the value is < 3.0, fish become slimmer, slender and lengthier with negatively allometric growth, while $>3.0$ indicates that the fish is wider or deeper with positive allometry with a rounder or slimmer body ${ }^{[31]}$. In isometric growth the body parts grow in the same proportion in all dimensions ${ }^{[20,32-37]}$. The value of ' $b$ ' in present study ranged between 2.265 to 2.853 (Table 3) showing a slightly negative allometric growth. Based on these interpretations, the present length-weight relationship ' $b$ ' value might reflect somewhat stressed conditions in the cages. The feed supplied to the trout requires highly balanced with high protein or complete diet ${ }^{[29,38]}$. Otherwise, high FCR should make lowers by supplying the quality feed. Wynne ${ }^{[7]}$ suggested that trout should be fed the feed consist of $38 \% \mathrm{CP}$ and $12 \%$ fat at the rate of $2-5 \%$ of their body weight in cages and feed should be reduced when water temperature drops below $10{ }^{\circ} \mathrm{C}$ during mid-winter. However, fish totally depend on local pellet feed having 33\% CP with $11 \%$ moisture and only $7.2 \%$ lipid for their growth in this study. Quality of feed with level of protein and other nutrients should be improved for further studies. FCR was expected 1.5:1 to 2.3:1 feed to fish by Wynne ${ }^{[7]}$ and he stated that FCR in cage-fish may be less efficient when sinking feeds are used.

Other than feed, the water temperature (Fig 9), dissolved oxygen and $\mathrm{pH}$ (Fig 10) were within the optimum range. In some studies, where rainbow trout showed negative allometric growth, has been explained that in some phase of the life fish may show such a trend ${ }^{[23,24]}$. The exact relationship between length and weight differs among species and according to their inherited body shape, and within a species according to the condition or robustness of individual fish ${ }^{[39]}$. These fundamental features were considered to make basic ideas for conceptualizing the present study.

For well-being of the trout the condition factor is expected to be higher than $1.0^{[40]}$. According to Barnham and Baxter ${ }^{[25]}$, if the $\mathrm{K}$ value is $1.60 ; 1.40 ; 1.20 ; 1.0$ and 0.80 , these indicates excellent and trophy class fish; a good and well-proportioned; a fair; poor long and thin; and finally extremely poor fish having disproportional large head and narrow skinny body, respectively. The present range of $\mathrm{K}$ value, 1.177-1.233 in harvesting month, April (Table 4) clearly indicated the suitability of the environment for rainbow trout in cages installed in reservoir for good growth. However, it might be argued that the trout cultivation in cages require more attention in various aspects to be ranked as an excellent trophy or a good and well-proportioned class fish for maximizing the benefit ${ }^{[25]}$.

Besides the confirmation by length-weight relationship, the $\mathrm{K}$ factor, feasibility and suitability of rainbow trout growth in cage culture was examined and it supported by the absolute growth rate (AGR) parameter. The AGR in terms of gain the total length and body weight in present study were within the range as suggested by earlier studies ${ }^{[41]}$. However, the AGR may vary depending on age, size, feed, water quality etc in rainbow trout. In present study we reared the fish in substantially low densities than previous studies where the growth were examined at 120, 160 and 200 fish.m ${ }^{-3}$ densities with high stocking individual weight of $100 \mathrm{~g}$ average body weight ${ }^{[41]}$. Soderberg and Meade ${ }^{\text {[42] }}$ showed no density effects on growth rate in Atlantic salmon. Contrarily Trzebiatowski et al. ${ }^{[21]}$ showed that growth and survival of rainbow trout depend inversely to the stocking density when stocked in higher density such as 150, 300, 600 and $900 \mathrm{~m}^{-3}$.

According to Beem and Gebhart ${ }^{[16]}$ the upper stocking limit of trout in cage generally considered to be 523 fish per cubic meter, but recommends lower stocking density if cage has to be installed in smaller water body. In small reservoirs, it is more likely to have poor dissolved oxygen (DO) supply for fishes. Since we worked in a small and shallow reservoir for growing first time, therefore the stocking density kept low with average stocking size, $57.6 \mathrm{~g}$ each. Schuler ${ }^{[43]}$ examined absolute growth rate in cages having stocking densities of 35 , 52 , and 70 fish. $\mathrm{m}^{-3}$ where the mean daily weight gain was 0.32 to $0.46 \mathrm{~g}$. The daily weight gains per fish were 2-3 times higher in present study comparing to the findings of Maher ${ }^{[11]}$. Barnham and Baxter ${ }^{[25]}$ suggests that the $K$ value can be used in determining the stocking rate of trout in particular water, if the $\mathrm{K}$ value reaches an unacceptably low level the 
stocking rate can be reduced accordingly until the $\mathrm{K}$ value improves and reaches an acceptable level. Larger values of $\mathrm{K}$, indicates better physiological condition while the low value suggest stressed, diseased or stared condition due to higher stocking density or unsuitable environment such as mismatching water temperature, and other aquatic conditions, pollution or poor food sources.

Absolute growth rate (AGR) in length of fish was somewhat low in the cage having stocking rate of 20 fish. $\mathrm{m}^{-3}$. The reason for this low growth is not clearly known. The results of some studies observed higher growth rate in fish cages where demand feeder were installed to feed the trout [11, 40]. We implied only the hand feeding in present study. Cren [11] depicted that fish exhibit highly proportionate growth in length and weight representing the surrounding environment or farming conditions or habitat or water quality, climate, feed and stages of maturity. The exact relationship between length and weight differs among fish species according to inherited body shape and within a species according to the condition (robustness) of individual fish.

Besides the length-weight relationship and condition factor additionally an aquaculturist desire to examine the AGR in terms of gram or centimetre per day unit for numerical representation of growth. Usually small and large fish have low absolute growth rates while fish of intermediate sizes have higher absolute growth rates ${ }^{[18]}$. The estimate of absolute growth rate (AGR) in terms of body weight and total length in present study were within the satisfactory range targeting to produce approximately $200 \mathrm{~g}$ average size trout at harvesting.

\section{Conclusion}

The present study showed that the rainbow trout can be reared in cages in shallow reservoirs especially during winter-spring season when temperature $\left(10-20^{\circ} \mathrm{C}\right), \mathrm{DO}(8-9 \mathrm{mg} / \mathrm{L}), \mathrm{pH}(6-$ 9), turbidity, alkalinity etc. are within the range. This preliminary study gives an idea that the rainbow trout can be stocked at $10-20$ fish. ${ }^{-3}$ to achieve high survival (96.6 $\pm 1.7 \%)$, good growth rate $(0.8 \pm 0 \mathrm{~g}$ per fish) with fair condition factor $(1.2 \pm 0.1)$ and reasonable productivity $(89 \pm 27$ $\mathrm{kg}$ per cage). Regression models indicated that productivity can be increased by increasing stocking density beyond 20 fish. $\mathrm{m}^{-3}$. With a view to enhancing productivity and taking advantage of economy of scale, more comprehensive research should be done applying higher densities, different feeding rates/methods and also conducting for longer period which may further enhance the productivity thereby profitability.

\section{Acknowledgement}

We express our gratitude to Kathmandu University for funding this study. Thanks to Vice-Chancellor Prof. Dr. Ram Kantha Makaju Shrestha and Professor Dambar Bahadur Nepali for their interest and encouragement. We are also thankful to Nepal Electricity Authority for the research site and their cooperation.

\section{References}

1. Nepal AP, Basnyat SR, Lamsal GP, Joshi PL, Mulmi RM. Economics of Rainbow Trout Farming System in Nepal. In: Petr T, Swar DB. (Eds.), Coldwater Fisheries in the Trans-Himalayan Countries. FAO Fisheries Technical Paper, 431. Food and Agriculture Organization of the United Nations, Rome 2002, 179-191. http://www.fao.org/3/a-y3994e.pdf

2. Rai AK, Bhujel RC, Basnet SR, Lamsal GP. Rainbow trout (Oncorhynchus mykiss) culture in the Himalayan
Kingdom of Nepal - a success story. APAARI, FAO Regional Office for Asia and the Pacific, Bangkok. APAARI Publication no. 2005/1. 2005. http://www.apaari.org/wpcontent/uploads/2009/05/ss_2005_01.pdf

3. Gurung TB, Wagle SK, Nepal AP, Lamsal GP. Rainbow trout (Oncorhynchus mykiss) based muntain aquaculture in Nepal. Nepalese Journal of Aquaculture and Fisheries. 2018;3(4):12-20.

4. Austreng E, Storebakken T, Åsgård T. Growth rate estimates for cultured Atlantic salmon and rainbow trout. Aquaculture 1987;60(2):157-160. https://doi.10.1016/0044-8486(87)90307-3

5. Sedgwick SD. Trout Farming Handbook. Fishing News Books Ltd. Surrey, England 1985.

6. Jiang X, Dong S, Zhou Y, Gao Q, Pan Z. An Effective Method of Prompting Juvenile Rainbow Trout (Oncorhynchus mykiss) to Cope with Heat Stress. Journal of Ocean University of China 2020;19:216-224. https://doi.org/10.1007/s11802-020-4124-y

7. Wynne F. Winter Culture of Caged Rainbow Trout in the South. Aqualculture Publication Fact Sheet, Collage of Agriculture, Food and Environment 2015. http://aquaculture.ca.uky.edu/publication/winter-troutculture-caged-rainbow-trout-south

8. Woynarovich A, Hoitsy G, Moth-Poulsen T. Small-scale rainbow trout farming. FAO Fisheries and Aquaculture Technical Paper No. 561. Rome, FAO. 2011, 81.

9. Bista JD, Gurung TB, Wagle SK, Karki GB, Dhakal RP. Cage culture of rainbow trout (Oncorhynchus mykiss) in stagnant water in lake and reservoir [Paper presentation], Asian Fisheries Society 7th Asian Fisheries Forum, Penang, Malaysia, 2004. http://sdg.iisd.org/events/seventh-asian-fisheries-forum/

10. Batajoo RK, Shrestha MK, Pandit NP. Possibility of rainbow trout (Oncorhynchus mykiss) culture in Phewa lake of Pokhara. Journal of Institute of Agriculture and Animmal Science 2007;28:115-120.

11. Maher JP. "Rainbow Trout Cage Culture Utilizing Different Strains, Stocking Densities, and Feeding Methods in Eastern South Dakota Dugout Ponds". Theses and Dissertations 1987;169. https://openprairie.sdstate.edu/etd/169

12. Cornel GE, Whoriskey FG. The effects of rainbow trout (Oncorhynchus mykiss) cage culture on the water quality, zooplankton, benthos and sediments of Lac du Passage, Quebec. Aquaculture 1993;109(2):101-117. https://doi.org/10.1016/0044-8486(93)90208-G

13. Clayton RD, Morris JE. Managing Iowa Fisheries: Cage Fish Culture, Iowa State University Joseph 2009. jemorris@iastate.edu

14. Dikel S, ÖZ M, Özşahinoğlu I. Cage culture potential of rainbow trout in Seyhan Dam Lake. $1^{\text {st }}$ International Conference on Engineering and Natural Sciences, May 15-19, at: Skopje Macedonia. Çukurova Universty Faculty of Fisheries Department of Aquaculture 2015. www.icens.eu

15. Karakoca S, Topcu A. Rainbow Trout (Oncorhynchus mykiss) Cage Culture: Preliminary Observations of Surface Sediment's Chemical Parameters and Phosphorus Release in Gokcekaya Reservoir, Turkey. Journal of Geoscience and Environment Protection 2017;5:12-23. https://doi.org/10.4236/gep.2017.54002

16. Beem M, Gebhart G. Cage Culture of Rainbow Trout. Langston University Extension Facts. Langston University. PO Box 1500, Langston, Oklahoma 73050, 
USA 1984. https://www.langston.edu/cage-culturerainbow-trout-(2017).

17. Cren EDL. The Length-Weight Relationship and Seasonal Cycle in Gonad Weight and Condition in the Perch (Perca fluviatilis), Journal of Animal Ecology. 1951;20(2):201-219.

(www.jstor.org/stable/1540)

18. Hopkins KD. Reporting Fish Growth: A Review of the Basics'. Journal of the World Aquaculture Society 1992;23(3):173-179. https://doi.org/10.1111/j.17497345.1992.tb00766.x

19. Subba S, Adhikaree S. Studies on Length-weight and Length-length Relationships of a Cold Water Fish Neolissochilus hexagonolepis (McClelland) from Tamor River, Nepal. Our Nature 2011;9:168-172. https://doi.org/10.3126/on.v9i1.5748

20. Shah TH, Balkhi MUH, Asimi OA, Khan I. Length weight relationship and ponderal index of rainbow trout (Oncorhynchus mykiss W., 1792) from Dachigam stream in Kashmir, African Journal of Agricultural Research. 2013;8(14):1277-1279. https://doi:10.5897/AJAR09.367

21. Trzebiatowski R, Filipiak J, Jakubowski R. Effect of stock density on growth and survival of rainbow trout (Salmo gairdneri Rich.). Aquaculture 1981;22:289295. https://doi.10.1016/0044-8486(81)90155-1

22. Holm JC, Refstie T, Bø S. The effect of fish density and feeding regimes on individual growth rate and mortality in rainbow trout (Oncorhynchus mykiss). Aquaculture. 1990;89(3, 4):225-232. https://doi.10.1016/00448486(90)90128-a

23. Sharma RK, Bhat RA. Length-weight relationship, condition factor of rainbow trout (Oncorhynchus mykiss) from Kashmir waters. Annals of Biological Research. 2015;6(8):25-29. www.scholarsresearchlibrary.com

24. Ahmad I, Ahmed I. Length Weight Relationship and Condition Factor of Cultured Rainbow Trout, Oncorhynchus mykiss (Walabum, 1792). Journal of Ecophysiology and Occupational Health. The Academy of Environmental Biology, India 2019;19(1, 2):24-27. https://10.18311/jeoh/2019/22304

25. Barnham C, Baxter A. Condition Factor, K, for Salmonid Fish 1998. FN0005, ISSN 1440-2254. State of Victoria, Department of Primary Industries 2003. https://bamboorods.ca/Trout\%20condition\%20factor.pdf

26. Kuriakose $\mathrm{S}$. Estimation of length weight relationship in fishes, Fishery Resources Assessment Division ICARCentral Marine Fisheries Research Institute, Reprinted from the CMFRI, FRAD. Training Manual on Fish Stock Assessment and Management 2014, 150.

27. Lugert V, Thaller G, Tenes J, Schulz C, Krieter J. A review on fish growth calculation: multiple functions in fish production and their specific application. Reviews in Aquaculture. Wiley Publishing Asia Pty Ltd 2014, 30-42. https://doi.org/10.1111/raq.12071

28. Okumus I, Celikkale MS, Kurtoglu IZ, Bascinar N. Growth performance, food intake and feed converison ratios in rainbow (Onchorynchus mykiss) and brook trout (Salvelinus fontinalis) reared as a single and mixed species. Turkish Journal of Veterinary and Animal Sciences 1999;23:123-130. https://journals.tubitak.gov.tr/veterinary/abstract.htm?id= 2628

29. Kljajic Z, Gacic Z, Mickovic B, Lazarevic B. Growth of rainbow trout (Oncorhynchus mykiss) reared in floating cage in the Bay of Kotor, Studia Marina 2014;27(1):97108. http://mne-mpa.org/wp-content/uploads/2015/09/
30. Abidi SAH, Desai BN, Gautam OS. The length-weight relationship in Sardinella sirm Wal from the Andaman Sea. Journal of the Indian Fisheries Association 1978;89:15-19. http://aquaticcommons.org/15853/1/JIFA89_015.pdf

31. Sangun L, Akamca E, Akar M. Weight-Length Relationships for 39 Fish Species from the North-Eastern Mediterranean Coast of Turkey. Turkish Journal of Fisheries and Aquatic Science 2007;7(1):37-40. http://www.trjfas.org/uploads/pdf_310.pdf

32. Carlander KD. Handbook of freshwater fishery biology. Dubuque, Iowa, Wm. C. Brown Co1950, 281.

33. Bagenal TB, Tesch FW. Age and Growth Methods for Assessment of Fish Production in Fresh Waters. In: Bagenal T. (Eds.), $3^{\text {rd }}$ Edition, IBP Handbook No. 3, Blackwell Science Publications, Oxford 1978.

34. Siegfried CA. Seasonal abundance and distribution of Crangon franciscorum and Palaemon macrodactylus (Decapoda, Carida) in the San Francisco Bay-Delta. Biological Bulletin 1980;159(1):177-192. https://doi.org/10.2307/1541017

35. Uye S. Length-weight relationships of important zooplankton from the Inland Sea of Japan. Journal of the Oceanographical Society of Japan 1982;38:149-158. https://doi.org/10.1007/BF02110286

36. Hopcroft RR, Roff JC, Bouman HA. Zooplankton growth rates: the larvaceans Appendicularia, Fritillaria, and Oikopleura in tropical waters. Journal of Plankton Research https://doi.10.1093/plankt/20.3.539

37. Tarkan AS, Gaygusuz O*, Acıpınar H, Gürsoy C, Zulug MO*. Length-weight relationship of fishes from the Marmara region (NW-Turkey). Journal of Applied Ichthyology. Blackwell Verlag, Berlin 2006;22(4):271273. https://doi.10.1111/j.1439-0426.2006.00711.x

38. FAO. Aquaculture Feed and Fertilizer Resources Information System, In: Frequently asked questions (FAQ) 2020. http://www.fao.org/fishery/affris/speciesprofiles/rainbow-trout/faqs/en/

39. Cella-Ribeiro A, Hauser M, Nogueira LD, Doria CRC, Torrente-Vilara G. Length-weight relationships of fish from Madeira River, Brazilian Amazon, before the construction of hydropower plants. Journal of Applied Ichthyology www.studiamarina.ac.me

40. Akbulut B, Sahin T, Aksungur N, Aksungur M. Effect of initial Size on Growth Rate of Rainbow Trout, Oncorhynchus mykiss, Reared in Cages on the Turkish Black Sea Coast. Turkish Journal of Fisheries and Aquatic Sciences 2002;2:133-136.

41. Kayim M, Suiçmez M, Güner Y, Suiçmez T. Growth of Rainbow Trout (Oncorhynchus mykiss, W. 1792) in Net Cages in Almus Dam Lake (Tokat). Pakistan. Journal of Biological Sciences 2007;10(6):964-967. https://doi.10.3923/pjbs.2007.964.967

URL: https://scialert.net/abstract/?doi=pjbs.2007.964.967

42. Soderberg RW, Meade JW. Effects of rearing density on growth, survival and fin condition of Atlantic Salmon. The Progressive Fish-Culturist 1987;49(4):280-283. https//:doi.10.1577/1548-

8640(1987)49<280:EORDOG>2.0.CO;2

43. Schuler GD. Rainbow trout cage culture and benthic production in east-central South Dakota dugouts. Masters thesis. South Dakota State University, Brookings, South Dakota, USA 1984. 